\title{
Research on the Fusion Path of Core Values of Socialism and College Students' Ideological and Political Education in the New Era
}

\author{
Mei Wang \\ Chongqing Business Vocational College, Chongqing, 401331, China
}

Keywords: New era, Core values of socialism, Ideological and political education, Fusion.

\begin{abstract}
University students are in a transition period from campus life to social life, students' ideological understanding level is gradually improving, but the thought development is not mature enough, at this time, the implementation of positive and effective ideological and political education for university students can promote the healthy growth of students and indicate the direction for the future development of students. This paper starts from the relationship between socialist core values and ideological and political education under the background of the new era, grasps the ideological and political education needs in the new era and explores the corresponding fusion path, hoping to further play the important role of ideological and political education and ensure the healthy growth of the students.
\end{abstract}

\section{Introduction}

General Secretary Xi Jinping clearly puts forward in the report of 19th CPC National Congress that ideal and faith education should be widely carried out in the new era, taking the propaganda and education of socialism with Chinese characteristics and the Chinese dream as an important educational content, carrying forward the Times spirit and national spirit in the work of talent training, and promoting the effective implementation of the education for patriotism, collectivism and socialism, gradually guiding the public to establish correct historical view, national view, cultural view and national view, and training the talents into high quality talents who can devote themselves to the cause of social construction. Therefore, in the education practice, the universities should pay attention to consciously explore the integrated measures of ideological and political education and value education, and optimize the talents training.

\section{The basic connotation of core values of socialism}

The core values of socialism are actually the characteristic values formed in the course of the development of socialist construction, the overview and basic ideas of the core value system. It is the core idea in the process of socialist construction, which plays a guiding role in the social construction activities. In general, the core values of socialism occupy a dominant position in the values system and can play a guiding role in the formation of other social values [1]. Since the 18th CPC national congress, our country has proposed to advocate prosperity, democracy, civilization and harmony, to advocate freedom, equality, justice and the rule of law, and to advocate patriotism, professionalism, integrity and friendship, cultivating and practicing the socialist core values actively. It is necessary to study and analyze the direction of national construction from multiple angles. It plays an important role in supporting the construction of socialist harmonious society with Chinese characteristics. Contemporary college students are the main power in social construction, undertake the important task of national construction and social construction. When ideological and political teachers of universities explore the ideological and political education, they should explore the measures of combining core values with ideological and political education, on the basis of comprehensively grasping the needs of the times and the practical demands of talents training, integrate socialist core values into the practice of ideological and political education, to optimize the ideological and political education, improve the quality of talents training in colleges and universities, and lay a talent foundation for social construction. 


\section{The close relationship between the core values of socialism and the current ideological and political education of university students.}

There is a close link between the ideological and political education of college students and the education and training of socialist core values. Combined with the current situation of talent cultivation in colleges and universities, it is found that the relationship between them can be grasped from the following perspectives:

First of all, the core values of socialism can correctly guide the understanding of college students, so specific to the ideological and political education, we can strengthen the foundation of ideological and political education of college students. There is appropriate description of socialist core values in the report of 18th CPC National Congress, it is believed that it is closely related to the development of national construction, social development and social individuals, and conveys the yearning for a better society, and also has an effective standard for the moral behavior of citizens. The content of socialist core values is relatively simple although, but with strong cohesion, involving all aspects of the construction of the social ideology, and can guide the optimization of the ideological and political education activities carried out. The organic combination of ideological and political education and values education can make college students correctly grasp the basic situation of society construction of our country. Under the realistic social background of multi-value orientation, we will gradually guide college students to realize the unified development of value orientation, and provide corresponding support and guarantee for the healthy growth of college students [2]. Study from this angle, we can see that values education has a certain thinking guidance function and can make a correct value guidance to ideological and political education. While highlighting the teaching effect, the ideological understanding of college students can be deepened, values education ensures that students establish correct outlook on life and values and has an important influence on the innovation and development for talents cultivation in colleges and universities.

Secondly, the ideological and political education is the important education contents to guide the healthy growth of college students. The growth of the students needs to be fused into the core values education. It can assist the comprehensive optimization of the practice and cultivation work of socialist core values and highlight the influence of socialist core values education. Analyzing ideological and political education in colleges and universities is, it is found that to implement the ideological and political education to the group of college students is to educate and influence the students in a planned and organized way mainly from the angle of ideological concept, ethics, politics concept and legal system consciousness. Ideological and political education of college students is to educate and guide the students in an organized and planned way on the basis of the comprehensive grasp of the students' characteristics and the development situation of the new era, to ensure that the college students' ideological concept can be adapted to social development demand, and with the help of college students to affect people around, promote the construction and development [3]. To analyze from this angle, the ideological and political education of college students plays an important role in talent cultivation work. Under the background of the change in the current social demand of talents, college students bear the responsibility of country prosperous and the great rejuvenation of the Chinese nation and Chinese dream, we should actively explore the reform and innovation measures of ideological education. During the course of practical education, we can try to merge into the ideas of core values, create conditions for the practice and cultivation of the core values, and then the core values can play an auxiliary role. The innovation of the form and content of ideological and political education make a corresponding positive impact on the construction and development of our society.

\section{The path of the socialist core values of the new era fused into the ideological and political education of university students.}

In order to ensure the optimization of the ideological and political education of college students, lay a solid foundation for the socialist core values education, we should actively explore the corresponding education and reform measures, organically combine the core values of socialism with 
the ideological and political education of university students, exert the two forces, to achieve more significant effect of college students cultivation.

\subsection{To improve organically the education mechanism of ideological and political in colleges and universities.}

Under the background of the new era, ideological and political education college has changed, colleges and universities should follow the trend of the times to optimize the education practice. To highlight the actual effect of ideological and political education, new media technology should be organically integrated into the process of the integration of socialist core values. With the power of new media, we can promote the implementation of socialist core values in the ideological and political education and make the correct ideological guidance for college students. The organization department of ideological and political education in colleges and universities should strengthen the application of new media technology and highlight the advantages of ideological and political education of the micro era. In the construction and improvement process of ideological and political education mechanism, with the guidance of socialist core values, it can highlight the main status of the students and extend ideological and political education to all aspects of college students' life from multiple perspectives. In this way, the influence of ideological and political education on college students' growth is further strengthened [4]. At the same time, in the process of combining socialist core values with ideological and political education, with the application of new media technology, we can realize the complementary advantages between traditional education activities and new media education and promote the optimal utilization of education resources. In this way, we can provide college students the requirements of times and a high recognition of the ideological and political education by teachers and students. To guarantee that the ideological and political education can adapt to the practice and cultivating of socialist core values and adapt to college students' learning life and the future social development. In this way, we can guarantee of the cultivation of university talents can be integrated into the process of construction of the times and contribute to socialist modernization construction of our country.

\subsection{Reform and innovation of teaching form of ideological and political practice}

The practice of ideological and political education is an important carrier to strengthen the ideological and political education, practice and of cultivating of socialist core values, so in the exploration of combining socialist core values and ideological and political education, the importance of classroom teaching should be correctly understood. We should actively implement reform and innovation in the teaching activities of ideological and political class, and exert the important role of ideological and political class teaching, put practice and cultivation of socialist core values into to practical teaching activities. Through systematic study, college students can form a deep understanding of socialist core values, be aware of what is inside and act on the outside, which effectively promotes the healthy growth of college students. So in teaching practice, the school can positively organize and design various types of ideological and political education activities in combination with the practical situation of the new era. With the combination of the classroom teaching, online teaching and extracurricular practice, we can optimize the ideological and political education from various angles and promote the optimization and innovation of talent cultivation [5]. In extracurricular activities, for example, after finishing the interpretation of the classroom teaching contents, to allow students to form a more scientific understanding of ideological and political knowledge of socialist core values, to promote the cultivation of students' ideological and political accomplishment. Teachers on the one hand can organize students to participate in the activities of socialist core values of the corresponding school community. Students in the community conscientiously accomplish activities that can reflect socialist core values. They are also required to complete the recording and writing of the activity perception and experience. Students' understanding of socialist core values can be deepened in this way. On the other hand, the school can also organize the students to participate in the social volunteer activities, so that they can practice the core values of socialism on the basis of serving the society. In this way we can deepen the students' ideological understanding, and lay a solid foundation of strengthening the students' ideological awareness level 
and healthy growth. With the help of reform the innovation of ideological and political class teaching in colleges and universities, the influence of ideological and political education will be further highlighted. We can create favorable conditions for the practice and cultivation of socialist core values and provide comprehensive support for the reform and innovation of the talent cultivation of universities and colleges.

\subsection{To strengthen the construction of new position of the campus culture education.}

Campus culture can support the optimization of the ideological and political education activities, plays a corresponding positive role in the practice and cultivating of socialist core values. So in the exploration of path of combing socialist core values with the ideological and political education in colleges and universities, we should take campus culture construction as an important carrier, and actively explore the construction of new position of campus culture, strive to improve the effect of ideological and political education under the influence of campus cultural environment, and ensure the full play of the guiding role of socialist core values. In the exploration of the construction of campus culture, colleges and universities can try to combine the education of culture educating people and culture cultivating people organically. Taking the practice and cultivation of socialist core values as the core measure to explore the construction of campus culture. Trying to integrate Chinese excellent traditional culture, modern elite culture and students career development related enterprise culture into the construction of campus culture to build a harmonious campus and create a positive and healthy environment for students' growth. So the role of the influence of culture on college students' to learning and growth can be further highlighted, to make sure that the effect of the fusion of socialist core values and ideological and political education can be fully and systematically exerted.

\subsection{To optimize the social environment}

College students are an important part of social groups, they will be affected by the social environment in the process of development, especially under the background of the Internet age, and information spreads more widely. Only to appropriately optimize the external social environment, the influence of social environment can play a role in promoting the effect of the education of ideological politics and the cultivation of socialist core values. In the process of optimizing the external social environment, on the one hand, the universities should contact the local media to consciously enhance the publicity of positive energy information and news. On the other hand, the universities should also purify the campus network, so as to prevent students from receiving bad information in school, and effectively improve the effect of ideological and political education. Only by this way, the ideological and political education of universities can realize the organic combination with socialist core values and create favorable conditions for students' future development.

\section{Conclusion}

In conclusion, in the practice of ideological and political education in colleges and universities, the core values socialism is an important value of leading the construction and development of social in our country. It plays an important role in promoting the construction of harmonious social and socialist modernization. So in the practice of the ideological and political education in colleges and universities, we should consciously explore the integration measures of ideological and political education and values cultivation. To improve the effect of ideological and political education and deepen the ideological understanding of college students, the schools can promote the cultivation of college students' national view, national outlook and collective view and create a good condition for the strengthening of the college students' ideological understanding level and moral emotion to make sure that college students after graduation can make contributions to the socialist construction cause.

\section{References}

[1] Ye Jia, Zeng Xiangui, The research on the implementation path of socialist core values education 
of the college students, Innovation and technology, 2013(9):90-91.

[2] Tian Xinhui, The study on the fusion mechanism of core values of socialism and the college students' ideological and political education, Knowledge economy, 2014(9):175-176.

[3] Zhao Huijuan, Sun Qinmin, The integration of the college students' ideological and political education and socialist core values in the new era, Journal of professional university, 2015(1):108-111.

[4] Zhang Dongyu, The research on the path of the college students' ideological and political education guided by socialist core values, Journal of Shenyang Institute of Engineering (social science edition), 2016(2):278-283.

[5] Xu Chunming, The study on the path of the college students' ideological and political education guided by socialist core values, Asia-pacific education, 2016(9):253-253. 